\title{
CORRUPTION AND IMPROPER PAYMENTS: Global Trends and Applicable Laws
}

\section{A. TIMOTHY MARTIN}

This article reviews recent changes in the law relating to bribes and other improper payments made in the course of conducting business in foreign countries. The author points to an emerging trend toward greater criminalization of such payments, and summarizes relevant Canadian and American law on the subject. The impact of multilateral agreements and international organizations is examined. The author also reviews laws against corruption and improper payments in Yemen, Libya, Nigeria, Kazakstan, Colombia, Venezuela, Indonesia and Vietnam.

In conclusion, the reader is presented with recommendations for achieving compliance with Canadian and American laws, as well as with those of specific host countries.
Le présent article examine les changements récents apportés au droit relatif aux pots-de-vin et autres paiements illicites dans le cadre des activités de commerce à l'étranger. L'auteur note une tendance d̀ la criminalisation accrue de ces pratiques et résume les décisions canadiennes et américaines pertinentes. L'incidence des accords multilatéraux et des organismes internationaux est examinée. L'auteur étudie aussi les lois anticorruption de divers pays - Yémen, Libye, Nigéria, Kazakstan, Colombie, Venezuela, Indonésie et Vietnam.

En conclusion, il propose des recommandations visant à promouvoir le respect du droit au Canada et aux Etats-Unis, ainsi que dans d'autres pays d'accueil.

\section{TABLE OF CONTENTS}

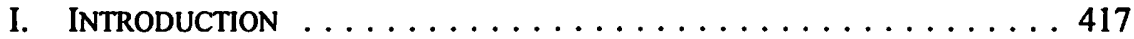

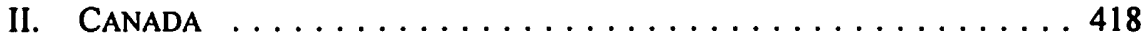

A. InTRODUCTION $\ldots \ldots \ldots \ldots \ldots \ldots \ldots \ldots \ldots \ldots \ldots$

B. Criminal Prohibitions $\ldots \ldots \ldots \ldots \ldots \ldots \ldots \ldots \ldots$

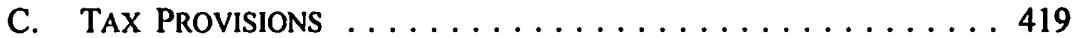

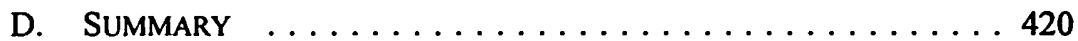

III. UNITED STATES $\ldots \ldots \ldots \ldots \ldots \ldots \ldots \ldots \ldots \ldots \ldots \ldots \ldots$

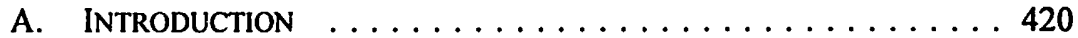

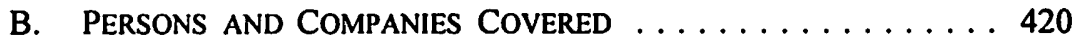

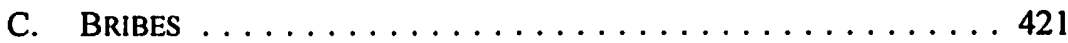

D. Facilitating Payments $\ldots \ldots \ldots \ldots \ldots \ldots \ldots \ldots \ldots 23$

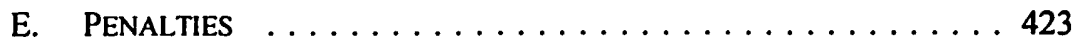

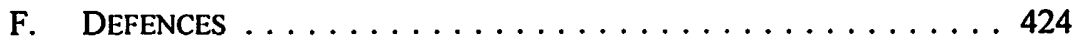

G. HISTORY OF FCPA ENFORCEMENT $\ldots \ldots \ldots \ldots \ldots \ldots 425$

H. EXTRATERRITORIALITY $\ldots \ldots \ldots \ldots \ldots \ldots \ldots \ldots \ldots$

I. TAX Provisions . . . . . . . . . . . . . . . . . 427

J. Preventative Measures $\ldots \ldots \ldots \ldots \ldots \ldots \ldots \ldots . \ldots 427$

IV. MUltilateral AgREEMENTS AND ORGANIZATIONS $\ldots \ldots \ldots \ldots 428$

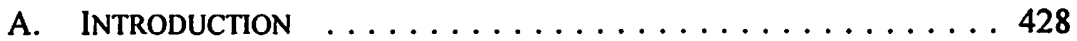

B. ORGANIZATION FOR ECONOMIC

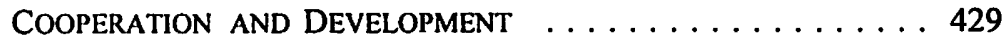

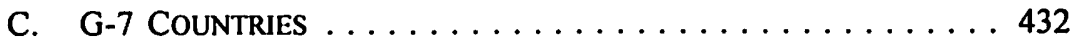

Vice President and General Counsel, International Canadian Occidental Petroleum Ltd., Calgary, Alberta. 
D. ORganization of AmERICAN States ... . . . . . . 432

E. ASIA-PACIFIC ECONOMIC COOPERATION FORUM ........ 433

F. WORLD TRADE ORGANIZATION ............. 434

G. International Chamber of Commerce . . . . . . . . 435

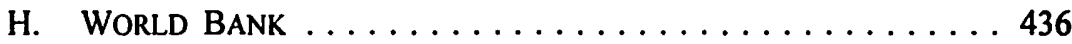

I. INTERNATIONAL MONETARY FUND . . . . . . . . . . . 437

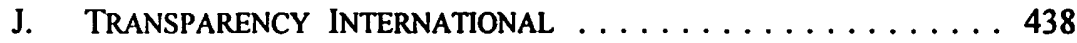

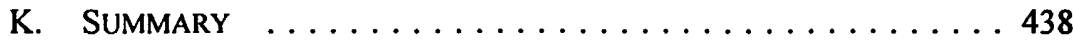

V. HoST COUNTRIES . . . . . . . . . . . . . . . . . . . . 440

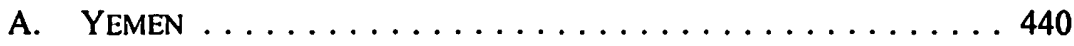

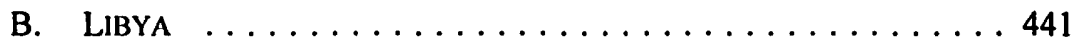

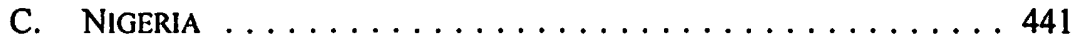

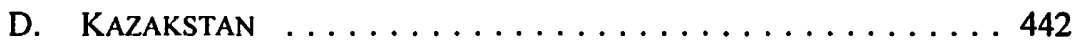

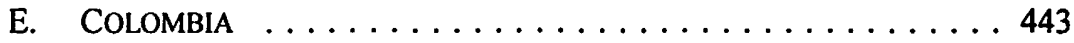

F. VENEZUELA $\ldots \ldots \ldots \ldots \ldots \ldots \ldots \ldots \ldots \ldots \ldots 44$

G. INDONESIA $\ldots \ldots \ldots \ldots \ldots \ldots \ldots \ldots \ldots \ldots \ldots 44$

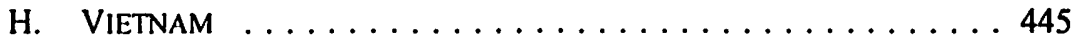

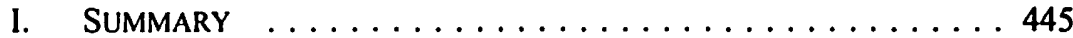

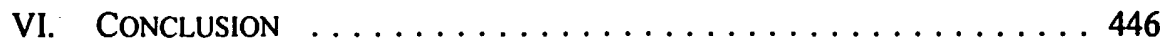

APPENDIX A - SAMPLE POLICY ............ 447

"Honesty pays, but it doesn't seem to pay enough to suit some people."

Kin Hubbard - American Humorist (1868-1930)

\section{INTRODUCTION}

Companies in Canada are used to a business environment in which corruption is infrequently encountered. When they pursue overseas business, these companies are often rudely surprised to find that the business practices in some countries are not so squeaky clean. Corruption is widespread in many developing countries and government officials in some areas of the world expect bribes as a normal course of business. Lacking clear guidelines, a company can quickly find itself in trouble when pressed by such demands.

This article discusses the laws on corruption and improper payments ${ }^{\prime}$ of which Canadian companies doing international business need to be aware. It reviews the laws of relevant jurisdictions and recent global trends in this area. Most countries in the

\footnotetext{
Throughout this article, the following definitions are used. An "improper payment" is either a bribe, kickback or an unreported facilitating payment. A "bribe" is an offering by one party to another party, who is a public official, either directly or through an intermediary, of any reward, advantage or benefit of any kind, in order to improperly influence the making or not making or implementation of a decision or act by the official concerned. A "kickback" is the payment or receipt of a portion of a contract payment usually as a result of collaboration. A "facilitating payment" is a payment made solely to expedite or secure the performance of routine government actions.
} 
world have some laws that prohibit bribery of public officials. However, with one exception (the United States), these laws tend to address only the bribery of domestic public officials. In the last several years, a number of events have occurred which will result in a larger group of countries, including Canada, enacting legislation that will criminalize the bribery of foreign officials. Specifically, the article:

(1) reviews the laws of Canada on improper payments;

(2) reviews the relevant laws of the United States;

(3) analyzes recent developments in multilateral agreements and organizations concerning improper payments;

(4) reviews anti-corruption laws in several host countries; and

(5) provides a sample corporate policy on improper payments.

\section{Canada}

\section{A. INTRODUCTION}

Canadian law prohibits the making of bribes to Canadian public officials; ${ }^{2}$ however, it does not currently contain specific provisions dealing with corruption and improper payments to foreign officials. ${ }^{3}$

\section{B. Criminal Prohibitions}

The Canadian Criminal Code is extensive in its coverage of improper payments to officials of the government of Canada and the provinces. Sections 118 to 123 cover improper payments made in Canada. However, they do not clearly address improper payments made by a Canadian firm or person to a foreign public official. ${ }^{4}$

\section{(1) FRAUDS ON THE GOVERNMENT - SECTION 121}

A bribe made to a public official in Canada to exercise influence or an act of omission in connection with government business is subject to a penalty of up to five years in prison. Section 121 is broad in scope and covers influence peddling. It prohibits improper payments to or for the benefit of government officials by or on behalf of those who have dealings with the government.

Criminal Code, R.S.C. 1970, c. C-34, ss. 118-23.

J.G. Castel, Extraterritoriality in International Trade: Canada and United States of America Practices Compared (Toronto: Butterworths, 1988) at 146.

J.M. Klotz, "Bribery of Foreign Officials - A Call For Change in the Law of Canada" (1994) 73

Can. Bar Rev. 467 at 475.

D. Watt \& M. Fuerst, The Annotated 1992 Tremeear's Criminal Code (Toronto: Carswell, 1991) at 179 . 


\section{(2) BRIBES ACCEPTED by HOLDERS OF JUdiCIAL OfFICES - SECTION 119}

Everyone who, "being the holder of a judicial office," corruptly accepts any money or other valuable consideration in respect of anything to be done in his official capacity commits bribery. This offence is punishable by imprisonment for up to fourteen years. Section 119 covers the acceptance of bribes by holders of judicial offices, including members of Parliament or of a provincial legislature.

\section{(3) BRibes to a Public OfFicer - SECTION 120}

Anyone who offers a bribe to a justice, police commissioner, peace officer, public officer, officer of a juvenile court, or employee in the administration of criminal law to facilitate the commission of an offence is guilty of an indictable offence. The punishment is imprisonment for up to fourteen years. The bribees are limited to individuals in Canada.

\section{(4) CONSPIRACY - SUBSECTION 465(3)}

There is an argument that s. 465(3) of the Criminal Code can be applied where there is corruption of foreign officials. This subsection could cover two kinds of conspiracies relating to foreign bribery: a conspiracy made "outside Canada" to bribe a Canadian official in Canada, and a conspiracy made "in Canada" to bribe a foreign official outside of Canada. The latter situation is of more importance to a Canadian company in its international operations.

In the Supreme Court of Canada decision, Libman v. $R .{ }^{6}$ the court considered the extraterritorial application of the conspiracy provisions of the Criminal Code. The court determined that if an offence is to be subject to the jurisdiction of Canadian courts, a significant portion of the activities constituting that offence must take place in Canada. There must be a "real and substantial link" between an offence and Canada before criminal liability will be imposed in Canada. The Supreme Court did not provide any detail of the specific factors required to identify such a link. Instead, the court provided an unclear guide for analysis of this issue, which will require an examination of the facts in each case. Where the scheme is "hatched" and largely put into effect in Canada, it is likely the court will conclude that Canadian criminal law applies. According to the Supreme Court of Canada, it is not yet clear whether a Canadian businessperson in another country, who delivers cash to a public official of that country in order to obtain a contract in that country, is subject to Canadian criminal law.

\section{Tax Provisions}

The Income Tax $A c t^{7}$ was amended in 1990 to prohibit the deductibility of illegal payments. Subsection $67.5(1)$ states: 
In computing income, no deduction shall be made in respect of an outlay made or expense incurred for the purpose of doing anything that is an offence under any of sections 119 to 121,123 to 125,393 and 426 of the Criminal Code or an offence under section $\mathbf{4 6 5}$ of that Act as it relates to an offence described in any of those sections.

Even though this section does not specifically speak to the bribery of foreign officials, Revenue Canada will likely reject any deduction made for overseas bribes.

\section{Summary}

It is a criminal offence to bribe Canadian public officials. However, Canadian law currently does not prohibit improper payments to foreign public officials except under very limited circumstances. This situation will likely change in the near future as a result of undertakings by the Canadian government in various multilateral agreements. ${ }^{8}$ The Canadian government is considering the introduction of legislation within the next year which will clearly criminalize improper payments to foreign officials. It is likely that legislation will be tabled in Parliament in the spring of 1998 and enacted by year end. The Income Tax Act will also likely be strengthened to clearly state that such payments are not deductible.

\section{UNITED STATES}

\section{A. INTRODUCTION}

The U.S. Foreign Corrupt Practices Act (FCPA) was enacted in December 1977 and amended in the Omnibus Trade and Competitiveness Act in August 1988. ${ }^{9}$ It has two parts. One part, entitled "Accounting Standards," establishes the rules governing the keeping of books and records and the establishment of internal control systems by all corporations registered with the Securities and Exchange Commission (SEC). The SEC administers this part of the Act. The other part of the FCPA is entitled "Foreign Corrupt Practices," and deals with payments to foreign government officials by any U.S. corporation, U.S. citizen or other entity falling within its jurisdiction. ${ }^{10}$ The U.S. Department of Justice and the SEC are each responsible for enforcement of the antibribery provisions of the $F C P A$, although the Department of Justice has sole authority over criminal prosecutions.

\section{B. Persons and Companies Covered}

The FCPA applies to the following persons and entities:

"Anti-bribery Legislation" The Globe \& Mail (4 November 1996).

Pub. L. 95-213, 91 Stat. 1494 (1977), as amended by Omnibus Trade and Competitiveness Act of 1988, Pub. L. 100-418, Title V, Sec. 5003(c), 102 Stat. 1107, 1419 (1988) (codified at 15 U.S.C. 78dd-1, 2).

10 B. Shaw, "Foreign Corrupt Practices Act: Amendments of 1988" (1990) 14 M. J. Int'] L. \& Trade at 161 . 
(1) "Domestic concern" - Any individual who is a citizen, national or resident of the United States or any corporation, partnership or other business organization which has its principal place of business in the United States.

(2) "Issuer" - Any company which has a class of securities registered with the SEC and any company which must file periodic reports with the SEC even though it may not be registered.

(3) Any officer, director, shareholder, employee or agent of a domestic concern or issuer. Such individuals can be prosecuted regardless of their nationality. However, foreign officials cannot be prosecuted under the FCPA.

In addition, even though foreign subsidiaries which are majority-owned by the domestic concern or issuer are not specifically covered by the $F C P A$, they may indirectly be covered by the application of SEC rules. This provision can be narrowly restricted to the accounting requirements of the $F C P A$. However, given the intent of the $F C P A$, it is unlikely that U.S. officials would condone the payment of bribes by foreign subsidiaries while at the same time condemning the failure to record facilitating payments.

As a result of the definition of "issuer" and the application of SEC rules to foreign subsidiaries, American officials will consider Canadian companies that are active in U.S. capital markets, and the foreign subsidiaries of such companies, as being subject to the $F C P A$. There are defences relating to sovereignty which are available; however, the reality is that a Canadian company that sources its financing in the United States needs to incorporate the FCPA into its compliance program.

\section{BRIBES}

The FCPA prohibits payments or offers of anything of value by a domestic concern or issuer to a foreign official, political party, party official or political candidate in order to influence corruptly any act within the recipient's official capacity, or to induce the recipient to violate his lawful duty, or to induce the recipient to use his influence with a foreign government to affect or influence any act or decision of such government for the purpose of obtaining or retaining business.

A "foreign official" under the $F C P A$ is defined as any officer or employee of a foreign government or any department, agency or instrumentality thereof, or any person acting in an official capacity for or on behalf of any such government or department, agency or instrumentality. The term "instrumentality" includes business corporations owned or controlled by a foreign government.

The "payment" clause of the $F C P A$ is broadly phrased. It covers not only the actual payment of money but also an offer, promise or authorization of the payment of money, and an offer, gift, promise or authorization of the giving of "anything of value." 
The "retaining business" clause has a broad reading and includes a prohibition against corrupt payments relating to the execution or performance of contracts or the carrying on of existing business, such as a payment to a foreign official for the purpose of obtaining more favourable tax treatment.

The FCPA uses the word "corruptly" in defining the act or event which is considered unlawful. The legislative history of the FCPA indicates that "corruptly" connotes an intentional wrongdoing or evil intent. Under U.S. law, the conduct and state of mind of any employee of a company acting within the scope of his employment can generally be attributed to the company for the purpose of criminal liability, even if the conduct at issue is contrary to company policy or directive. This has far-reaching implications if an employee is acting improperly in an overseas operation. In effect, a company may be held liable for the actions of a rogue employee.

The FCPA applies to any payment to any person by a payor who knows or believes there is a high probability that at least a portion of the money or thing of value "will be offered, given, or promised, directly or indirectly" to a foreign official, foreign political party, party official or candidate for public office in a foreign country. Thus, normal payments to independent third parties such as agents, lawyers, distributors, contractors, consultants and suppliers may be deemed to violate the $F C P A$ if it appears likely that the recipient made payments to foreign officials. The $F C P A$ requires "actual knowledge" of an improper payment before a company can be held liable for an indirect payment to a foreign government official. The "actual knowledge" standard reduces the risk of imputed liability. However, a company may not take a "head in the sand" attitude and consciously disregard overt corrupt activities by agents, consultants, and the like. The FCPA defines "knowing" as covering the inaction of corporate officials when reasonable signals of an $F C P A$ violation exist. Thus, the standard is one of "conscious disregard" of facts which would alert a reasonable person to probable violations. In addressing the standard, U.S. courts have held corporate officers liable even if they did not know that a third party actually made an illegal payment.

In summary, these are the elements of an $F C P A$ violation:

(1) the act is corrupt;

(2) there is a payment of money or anything of value;

(3) the payment is made to a foreign official or political party; and

(4) the purpose is to obtain, retain or direct business.

The FCPA covers payments made to third parties where "actual knowledge" exists that the payment will be made to foreign government officials. 


\section{Facilitating Payments}

Facilitating payments (also known as "grease payments") are not prohibited by the FCPA. This exception is limited to payments made to expedite ministerial or clerical (as opposed to discretionary) functions, i.e., "routine governmental action." The term "routine governmental action" is defined to include only those actions ordinarily and commonly performed by foreign government officials in connection with:

(1) obtaining licences, permits and other official documents to qualify to do business in a foreign country;

(2) processing governmental papers, such as visas and work orders;

(3) providing police protection, mail services and inspection of goods or of contract performance;

(4) providing telephone service, utilities, loading or unloading cargo and protecting perishable goods from deteriorating; and

(5) actions of a similar nature.

It is important that facilitating payments are recorded properly according to SEC rules. Failure to comply can lead to the imposition of severe penalties by the SEC, including injunctions relating to the way a corporation's operations are conducted. In the past, the SEC has charged a number of U.S. corporations with violations of the disclosure rules for failure to report publicly, in a timely fashion, on payments to foreign officials (including payments made by majority-owned foreign subsidiaries) regardless of the financial materiality. The record-keeping provisions of the FCPA require all publicly held companies to keep records that clearly indicate how their assets are used. The FCPA is intended to eliminate vaguely labelled accounting entries, such as "slush funds," which investigators found were often used to disguise bribery payments. Any accounting system which fails to clearly indicate how money is disposed of violates the FCPA. The SEC has, in fact, used the FCPA in several cases to prosecute wrongdoers who have not engaged in bribery of foreign officials, but whose actions technically violate the $F C P A$ 's accounting requirements.

\section{E. Penalties}

The criminal penalties for violating the $F C P A$ are severe. Corporations are subject to fines upon conviction of up to (U.S.) $\$ 2,000,000$ per offence. Individuals who violate the $F C P A$ are subject to prison sentences of up to five years and fines of up to (U.S.) $\$ 100,000$. The $F C P A$ states that fines imposed upon individuals may not be paid directly or indirectly by any corporation for which they have acted. Civil fines of up to (U.S.) $\$ 10,000$ may also be imposed against corporations and individuals. "The

" A. Fremantle \& S. Katz, "The Foreign Corrupt Practices Act Amendments of 1988" (1989) 23 Int'I Lawyer 755 at 766. 
Attorney General may also seek injunctive relief against domestic concerns which violate the FCPA.

It should be noted that, aside from the obvious concerns about prosecution and conviction under the $F C P A$, corporations are also severely affected by the publicity surrounding an FCPA investigation. At the end of the day, a company is usually not able to win against the sheer weight of the U.S. Government even though it might have a strong defence. The financial markets have taken note of this dilemma in the past.

\section{F. DEFENCES}

The $F C P A$, as amended, establishes two affirmative defences: ${ }^{12}$

(1) It is an affirmative defence that the payment in question was lawful under written laws and regulations of the foreign official's country. It is not sufficient that the payment in question is customary in the foreign official's country. There are few countries, if any, where such laws exist.

(2) It is an affirmative defence that the payment in question was a reasonable and bona fide expenditure (e.g., the reimbursement of the foreign official's travel and lodging expenditures), incurred in connection with and directly related to the promotion or demonstration of products or services of the company or to the execution or performance of a contract with a foreign government or agency. These expenses are intended to be those associated with reimbursement for a foreign official's reasonable and bona fide expenses and require a "common sense" approach.

One of the difficulties which the $F C P A$ does not directly approach is gifts given as a courtesy, a token of esteem or in return for hospitality. No positive defence was provided in the FCPA for these types of gifts. Evidently, the drafters intended the courts to address each individual case on the basis of whether the value of such nominal gifts is appropriate in the context of the specific transaction and on the local laws, customs and business practices in the host country.

There is an additionally recognized defence under the FCPA for payments made in respect of extortion demands. The law applies to payments which are in the nature of "bribes," but does not apply to payments made because of a threat of harm or violence to persons or property. There is some uncertainty as to whether payments for so-called economic extortion (as opposed to extortion involving physical harm to persons or property) fall within this exception.

For those companies requiring greater certainty, the U.S. Attorney General is required under the $F C P A$ to provide an advisory opinion within thirty days of a request. Approximately two dozen opinions have been published. 


\section{G. HISTORY OF FCPA ENFORCEMENT}

The majority of $F C P A$ cases have been under the accounting rather than the antibribery provisions of the $F C P A$. There have been sixteen cases prosecuted under the anti-bribery provisions of the $F C P A$ up to 1995 . The illegal payments have ranged from (U.S.) $\$ 22,000$ to (U.S.) $\$ 9.9$ million. All of the payments have been made in money, usually paid into third-country bank accounts. Seventeen companies (twelve domestic concerns and five issuers) and thirty-three individuals have been charged under the FCPA in connection with allegations of bribing foreign officials. ${ }^{13}$ The primary focus of Department of Justice prosecutions has been payments made to high-level government officials such as presidents, prime ministers, royal family members, ministry officials, military and police officers. ${ }^{14}$

In January 1995, Lockheed Corporation (Lockheed) resolved a U.S. government investigation by pleading guilty to $F C P A$ violations and paying (U.S.) $\$ 24.8$ million in fines and a (U.S.) $\$ 3$ million civil settlement. ${ }^{15}$ Two former Lockheed employees were found guilty. Allen Love, an American citizen and former Lockheed manager who cooperated with the investigation received a probationary sentence and a (U.S.) $\$ 20,000$ fine. The other employee, Suleiman Nassar, who was Lockheed's vice president of Middle East and North African marketing, fled to Syria after being indicted. He was extradited back to the United States in July 1995 and became the first person imprisoned for a FCPA conviction. Nassar was sentenced to eighteen months in prison and ordered to pay a (U.S.) $\$ 125,000$ fine.

The most interesting case involving a non-U.S. company is the recent civil suit filed 21 November 1996 by the SEC against the Italian firm Montedison, S.p.A. in which Montedison was accused of hiding millions of dollars in bribes. ${ }^{16}$ This case clearly shows that U.S. officials are now aggressively pursuing companies that have any association with the United States. In the case of Montedison, its stock trades as an American Depository Receipt (ADR) on the New York Stock Exchange. This is the first case in which the anti-bribery provisions of the FCPA have been applied to a nonU.S. company that qualifies as an issuer with the SEC, and in which all the corrupt activity occurred outside of the United States.

Montedison was accused of paying multi-million dollar bribes to Italian officials and was successfully prosecuted in the "clean hands" trials in Milan by Italian prosecutors. ${ }^{17}$ At the same time that the payments occurred, Montedison filed its

W.F. Pendergast, "Foreign Corrupt Practices Act: An Overview of Almost Twenty Years of Foreign Bribery Prosecutions" (1995) 7 Int'l Q. 187.

Remarks of R.M. Olsen, Special Counsel to the Associate Attomey General, United States Department of Justice, "Enforcement of the Foreign Corrupt Practices Act by the Reagan Administration" (1983) at 15.

U.S. v. Lockheed Corporation, Suleiman A. Nassar and Allen R. Love, Cr. No. 1:94-CR226 (N.D., Ga. Atlanta Div. June 1994).

SEC v. Montedison, S.p.A., Civ. No. 1:96CV02631 (D.D.C. filed 21 November 1996).

"Italy's Montedison is Accused by SEC Of Hiding Millions of Dollars in Bribes" The Wall Street Journal (22 November 1996) A4. 
financial reports with the SEC without disclosing that such payments had been made. ${ }^{18}$ As a result of information from the "clean hands" trials, the SEC is now claiming that Montedison disguised multi-million dollar bribes using two methods. First, Montedison described some payments as relating to a fictitious and eventually uncollectible loan, and second, it overstated the value of certain real estate which it later wrote down to the tune of (U.S.) $\$ 120$ million. There has been no reported resolution of this case at the time of writing.

Overall, it can be anticipated that FCPA enforcement will increase and become more severe. FCPA defendants are now sentenced under the new U.S. Federal Sentencing Guidelines, which means that there will be minimum incarceration of several years with no probation available. Corporate and individual fines will be increased substantially. The U.S. Department of Justice has publicly stated its continuing commitment to the aggressive enforcement of the $F C P A$.

\section{H. EXTRATERRITORIALITY}

There have been recent moves in the U.S. Congress and Senate to increase and extend the jurisdiction of their anti-bribery legislation beyond the borders of the United States and its corporations. This follows other recent trends of the U.S. extending its sanctions of certain countries (e.g., the Iran (Libya) Oil Sanctions $A c t^{19}$ and the LIBERTAD Act $^{20}$ (Helms-Burton Act) which imposed sanctions against Cuba). These legislative actions are a direct response to the continuing frustration of U.S. corporations which claim they lose business to foreign companies willing to pay bribes while U.S. companies are restricted by the FCPA.

Senator Russ Feingold (Democrat - Wisconsin) introduced Bill 576 which would prohibit certain U.S. trade assistance agencies from aiding U.S. subsidiaries of foreign corporations, unless the director of the agency certifies to Congress that the corporation maintains a company-wide policy prohibiting the bribery of public officials. No action has been taken on Senator Feingold's bill since its introduction in 1995.

A more far-reaching bill has been drafted by Senator Hank Brown (Republican Colorado) to pressure foreign companies and countries. The title of this draft bill is the Foreign Business Corruption Act of 1996 and includes the following:

(1) Section 301 of the Trade Act of $1974^{21}$ would be amended to include the toleration by a foreign government of its corporations or public officials' corrupt business practices as an unfair trade barrier to U.S. exports.

"Antifraud: SEC Charges Italian Concern With Scheme To Conceal Bribes" (1996) 28 Sec. Reg. L.R. 1492.

1.) Iran (Libya) Oil Sanctions Act of 1996, Pub. L. No. 104-172.

211 Cuban Liberty and Democratic Solidarity (LIBERTAD) Act of 1996 (Helms-Burton Act), Pub. L. No. 104-114, 110 Stat. 785.

$21 \quad 18$ U.S.C. $\$ 12(1976)$. 
(2) The FCPA would be amended to allow a private right of action by one U.S. domestic concern against other U.S. domestic concerns which engaged in corrupt business practices in foreign lands. The damage award could be up to three times the amount of actual damages for injuries sustained by the plaintiff.

(3) The Securities Exchange Act of $1934^{22}$ would be amended to allow any person a private right of action against an issuer under the SEC with similar damages as under the FCPA amendment.

(4) The president would be allowed to authorize any U.S. domestic person to bring an action in a U.S. district court against any foreign concern which violated a law of a foreign country that is substantially similar to U.S. legislation.

Senator Brown was not re-elected in 1996 and his bill has effectively disappeared; however, the threat of such legislation remains a possibility at all times.

\section{Tax Provisions}

Amendments to the U.S. Internal Revenue Code ${ }^{23}$ in 1958 prohibited a deduction for any direct or indirect payment that "would be unlawful under the laws of the United States if such laws were applicable to such payment and to such official or employee." Further amendments in 1992 permitted a business deduction for facilitating or "grease" payments if they did not violate the anti-bribery provisions of the FCPA.

\section{J. Preventative Measures}

A Canadian company that is subject to FCPA jurisdiction can ensure that its directors, officers and employees are not in breach of the FCPA and other applicable U.S. laws by making them aware of the provisions of such laws and requiring that all such matters are reviewed and considered by appropriately designated officers of the company. However, a major and often difficult area of exposure under the $F C P A$ involves the retention of foreign consultants or representatives and other service providers to assist a company in doing business abroad. This is particularly so where the consultant or representative is retained to assist the company in obtaining contracts with a foreign government or government-owned corporation, or in obtaining legislation, licences, permits or other governmental actions needed by the company or its ventures.

There are two basic steps a company can take to reduce the likelihood that a prohibited payment will be made by a consultant or representative to the official of a foreign government, and to minimize the risk that such a payment will be deemed to have been known of by the company if it does occur. First, the company can undertake to ascertain information regarding the background of the consultant or representative. Second, the company can, in a written agreement for the provision of the desired 
services, secure representations and warranties with respect to the consultants' intended disposition of the fees he is to receive.

When retaining a consultant or representative, there are certain "red flags" which may appear that, at a minimum, require further investigation. The following is a list of red flags that should raise questions:

(1) the payment is being made in a country with a widespread history of corruption;

(2) the representative refuses to confirm that he will abide by the provisions of the FCPA;

(3) the representative has family or business ties with government officials;

(4) the representative has a bad reputation in the business community;

(5) the representative requires that his identity not be disclosed;

(6) a government official recommends the representative;

(7) the representative makes unusual requests such as a request to backdate or alter invoices;

(8) the representative asks for commissions that are substantially higher than the "going rate" in that country;

(9) the representative asks for payment by unorthodox or convoluted means such as through bank accounts outside the country where the services are being offered;

(10) the representative requests cheques to be made out to "bearer" or "cash" or requests payments to be made in cash or some other anonymous form;

(11) there are multiple middlemen performing the same task; or

(12) the representative requests unusually large bonuses or substantial up-front payments.

\section{Multilateral Agreements and ORganizations}

\section{A. INTRODUCTION}

There is currently a wide-ranging initiative in multilateral organizations to restrict international corruption. This initiative is being led by the United States and is the second major attempt to address this issue in such organizations. 
The first time that an international effort was mounted was in the 1970s at the United Nations (U.N.) and was wholly unsuccessful. ${ }^{24}$ The United States pushed this multilateral effort because it was concerned that its unilateral action to outlaw bribery (the $F C P A$ ) put American businesses at a disadvantage in their international operations. A draft agreement known as the "International Agreement on Illicit Payments" was completed in $1979 .{ }^{25}$ This draft U.N. agreement outlawed all bribes to public officials, including the "grease" payments currently exempted under the $F C P A$. Although the text of this draft U.N. agreement was forwarded to the Council of the General Assembly, no action was ever taken to convene a conference to conclude and formalize it, despite strong efforts to do so by the U.S.

Having failed at the United Nations, the U.S. moved to another forum, the Organization for Economic Cooperation and Development (OECD). The U.S. government lobbied the OECD in 1981 to implement an illicit payments agreement. However, several countries expressed the view that differences among their legal systems would make such an agreement difficult to implement. Nothing resulted from these efforts.

A second attempt to put into place international agreements on the prevention of improper payments is once again being led by the United States. This attempt is gaining more ground within the international community. As a result, various multilateral agreements are being entered into and many international organizations have implemented policies to combat corruption.

\section{B. Organization for Economic CoOperation and Development}

In 1994, a suite of recommendations was agreed upon by a majority of the twentysix OECD countries, entitled OECD Recommendations on Bribery in International Business Transactions. ${ }^{26}$ This was the first multilateral agreement among governments to combat the bribery of foreign officials. However, it was not binding and was well below the objectives set by the United States. No specific measures were recommended under this agreement; rather, a broad list of "meaningful steps" was provided.

Subsequently, after intensive lobbying by the United States and after overcoming the resistance of some European countries (especially France), the OECD Council on 11 April 1996 approved the following recommendation to eliminate the tax deductibility of bribes among its member states:

UN GAOR, No. 3514, Measures Against Corrupt Practices of Transnational and Other Corporations, Their Intermediaries and Others Involved (1975).

25

26 
Those Member countries which do not disallow the deductibility of bribes to foreign public officials shall re-examine such treatment with the intention of denying this deductibility. Such action may be facilitated by the trend to treat bribes to foreign officials as illegal. ${ }^{27}$

The OECD met in May 1997 to review the steps taken by its member states to combat bribery. This included a review of the implementation of the above tax deductibility recommendation and it discussed the potential implementation of laws that would criminalize the bribery of foreign public officials.

The American government with the backing of most OECD members pushed for a resolution committing governments to outlaw foreign bribery in their domestic legislation by the end of 1998 and to establish a monitoring system to ensure that it was being enforced. In opposition, France and Germany, with the support of Japan and Spain, maintained that "you need an international convention for criminalizing corruption, because the legal framework in each country is different." ${ }^{28}$ The U.S. and its supporters viewed this as a stalling tactic since such treaties take many years to negotiate and ratify. ${ }^{29}$

After much negotiation, a compromise was struck. The ministers endorsed the Revised Recommendation on Combatting Bribery in International Business Transactions on 23 May $1997 .^{30}$ In particular, they reaffirmed their commitment to criminalize bribery of foreign officials in an effective and coordinated manner. They noted that an international convention in conformity with the common elements agreed to by members was an appropriate instrument to use to attain rapid criminalization. They recognized that achieving progress in this field requires not only efforts by individual countries, but multilateral cooperation, monitoring and follow-up. They recommended that member countries should submit criminalization proposals to their legislative bodies by 1 April 1998 and seek their enactment by the end of 1998. The ministers decided to promptly open negotiations on a convention to be completed by the end of 1997, with a view to its entry into force as soon as possible within 1998 and urged the prompt implementation of the 1996 recommendation on the tax deductibility of such bribes. The ministers also stressed the global relevance of bribery in international business transactions and called on non-OECD countries to join forces to fight this phenomenon. ${ }^{31}$

OECD, Committee on International Investment and Multinational Enterprises (CIMF), Implementation of the Recommendation on Bribery in International Business Transactions (OECD, 1996). This report was presented to the 1996 meeting of the OECD Council at the ministerial level. See also OECD "Recommendation on the Tax Deductibility of Bribes of Foreign Public Officials," adopted on 11 April 1996, c(96)27/FINAL.

28 P. Blustein, "Fight Looms Over Foreign Bribery" The Washington Post (9 May 1997) A22.

29 P. Lewis, "Straining Toward an Agreement on Global Bribery Curb" The New York Times (20 May 1997) D4.

30 Revised Recommendation on Combatting Bribery in International Business Transactions, OECD Document c(97)123/FINAL (23 May 1997).

31 OECD, "Meeting of the Council at Ministerial Level, Paris, 26-27 May 1997" News Release, Art. 29 (27 May 1997). 
The United States viewed the undertaking to complete an international convention by the end of 1997 as separate and distinct from the enactment of domestic legislation to criminalize bribery of foreign officials in each of the OECD countries by the end of 1998. The French, on the other hand, saw the two recommendations as linked and possibly leading to an interesting impasse if the international convention were not completed within the prescribed time frame.

Canada was represented at the OECD meeting by Douglas Peters, Secretary of State for International Financial Institutions, who stated that Canada already had legislation in place that the government considered adequate: "We have legislation that prohibits conspiracy and it is sufficient. If there is something further needed, then we will quickly do so. But as far as we know right now, the Canadian legislation is quite adequate." 32 This statement showed that Canada was fully cooperating in the fight against international corruption, and yet it provided the government sufficient flexibility in considering changes to its domestic legislation.

After six months of intensive and detailed discussions, all twenty-nine member countries of the OECD and five non-member countries agreed to sign the Convention on Combatting Bribery of Foreign Public Officials in International Business Transactions $^{33}$ in Paris on 17 December 1997. This Convention provided the framework under which all the signatory governments undertook to prohibit and act against the bribery of foreign public officials on an equivalent basis without requiring uniformity or changes in the fundamental principles of each government's legal system.

The Convention provided that:

(1) each government shall establish that it is a criminal offence under its law for any person intentionally to offer, promise or give any undue pecuniary or other advantage, whether directly or through intermediaries to a foreign public official, for that official or for a third party, in order that the official act or refrain from acting in relation to the performance of official duties, in order to obtain or retain business or other improper advantage in the conduct of international business; ${ }^{34}$

(2) the bribery of a foreign public official shall be punishable by effective, proportionate and dissuasive criminal penalties;

(3) in the event that criminal responsibility is not applicable to legal persons under a government's legal system, non-criminal sanctions shall apply;

32 M. Drohan, “U.S. Pushes for Stringent Bribery Rules" Globe and Mail (27 May 1997) B1.

3. Convention on Combatting Bribery of Foreign Public Officials in International Business Transactions (17 December 1997) [hereinafter Convention]. This convention was negotiated in the framework of the OECD but is not an official OECD document. For further information see (http:/l www.oecd.org/daf/cmis/bribery/20novle.h(m).

34 Interestingly, the commentaries issued by the OECD on this Convention stated that is not an offence if the advantage was permitted or required by the written law or regulation of the foreign public official's country. Also, making small "facilitation" payments is not an offence since they are not payments made "to obtain or retain business or other improper advantage." Both of these 
(4) the bribe and its proceeds are subject to seizure and confiscation;

(5) where more than one government has jurisdiction, they shall consult with a view to determining the most appropriate jurisdiction for prosecution;

(6) in order to protect the independence of prosecution, enforcement shall not be subject to improper influence by concerns of a political nature;

(7) governments shall establish accounting and auditing standards to prohibit the establishment of off-the-books accounts or recording or non-existent expenditures by companies for the purpose of bribing foreign officials or hiding such bribery;

(8) governments shall provide prompt and effective legal assistance to other governments in their investigations and proceedings and shall not use bank secrecy as grounds to decline mutual legal assistance;

(9) bribery of a foreign public official is considered an extraditable offence amongst the signatory governments; and

(10) all parties to the Convention shall cooperate in carrying out a program of systematic follow-up to monitor and promote the full implementation of the Convention.

Canada was a signatory to the Convention and, accordingly, has undertaken to implement legislation within the timetable stated above. It is therefore expected that by the end of 1998 the bribery of foreign public officials will be a criminal offence under Canadian law.

\section{G-7 COUNTRIES}

The G-7 ministers met in Lyon, France in July 1996. They supported the recommendations of the $\mathrm{OECD}$ and agreed to provide their weight to the implementation of those recommendations. ${ }^{35}$

\section{Organization of American States}

In a meeting held in Caracas, Venezuela in March 1996, the Organization of American States (OAS) adopted a "Convention Against Corruption." 36 Once again, the United States led the implementation of this convention, with strong support from several South American countries, including Venezuela. There was opposition to the treaty's extradition provisions from Colombia, and to the bank secrecy provisions from 1996). 
Uruguay. ${ }^{37}$ However, it was adopted in the end by the entire OAS and is now being ratified by individual states. Canada is a member of the OAS but has not ratified this convention at the time of writing.

All the countries to the convention agreed to the following:

(1) countries that have not yet done so shall adopt the necessary domestic laws to establish as criminal offences any of the acts of corruption described in the Convention;

(2) each country shall prohibit and punish the offering or granting, directly or indirectly, by its nationals, residents or businesses, to a government official of another state, of any article of monetary value or other benefit in connection with any economic or commercial transaction in exchange for any act or omission in the performance of that official's public functions;

(3) any country that has not established transnational bribery as an offence shall, in so far as its laws permit, provide assistance and cooperation with respect to this offence as provided in the convention;

(4) each of the offences established by each country shall be deemed to be included as an extraditable offence in any extradition treaty existing between or among the countries; and

(5) countries shall provide each other the broadest possible measure of assistance in the identification, tracing, freezing, seizure and forfeiture of property or proceeds obtained, derived from, or used in the commission of any offence established in accordance with the convention. ${ }^{38}$

\section{E. Asia-Pacific Economic CoOperation Forum}

The Asia-Pacific Economic Cooperation (APEC) Forum is made up of eighteen member states around the Pacific Rim. The United States and Canada are members of this forum. The heads of state from all eighteen members met in Manila, the Philippines, at the end of November 1996.

The United States pushed to have the APEC Forum approve similar recommendations as were adopted by the OECD. ${ }^{39}$ The United States wanted to have the deductibility of bribery payments disallowed under the APEC countries' tax codes and also wanted to criminalize the bribery of foreign officials. U.S. officials also sought greater transparency in government procurement policies since, in their estimation, this

OAS, Trade Promotion Coordinating Committee Report at 115. See also D. Lubick, Acting Assistant Secretary of the Treasury, "International Tax Issues" (13 December 1996).

OAS, Inter-American Convention Against Corruption (29 March 1996).

"Kantor Wants APEC Role in Countering Bribery" Jiji Press Ticker Service (7 March 1996). 
is the greatest area of bribery and corruption. ${ }^{40}$ Several Asian members of the APEC Forum publicly stated prior to the creation of the forum their misgivings about this proposal, citing cultural differences amongst the eighteen member economies. ${ }^{41}$

Nothing formally happened with this proposal. The APEC leaders' statement did not mention the subject, although the foreign and trade minister's statement made passing reference to it. $^{42}$

The APEC Forum convened again in Vancouver, British Columbia in November 1997. However, this time it met under a spreading financial crisis in Southeast Asia. Instead of aggressive denial to recommendations on government transparency, the assembled leaders deferred to the International Monetary Fund (IMF) to clean up the mess through country-by-country bailouts. ${ }^{43}$ The final APEC communique promised to respond "swiftly and effectively" to quell the economic turmoil but was predictably silent about mismanagement and corruption in the members' economies. ${ }^{44}$ The agenda of greater government transparency and elimination of corruption was thus quietly moved from the APEC Forum to the IMF, which would demand and get concessions under the loans that Thailand, South Korea, Malaysia and Indonesia so desperately needed.

\section{F. WORLd Trade Organization}

Trade ministers from Japan, the United States, Canada and the European Union agreed in a trade meeting in Kobe, Japan in April 1996 that bribery and corruption in government procurement contracts in developing nations were obstacles to the free trade system and that they (the ministers) would promote such a free trade system at the December 1996 World Trade Organization (WTO) Conference. ${ }^{45}$

Subsequently, WTO Director-General Renato Ruggiero stated that bribery was a "concern which is at least worth considering seriously." The Paris-based International Chamber of Commerce (ICC), comprising 7,000 companies and business groups, backed the U.S. proposal. Lionel Walsh, the Chamber's spokesman, stated "[c]orruption and bribery are a form of trade distortion, they distort the natural dynamics of trade." ${ }^{14}$

The WTO held its first-ever ministerial conference in Singapore from 9 to 13 December 1996, with attendance by the heads of state of WTO member countries. The United States, with support from Canada, the European Union, Japan, and nine other

D. Smith, "U.S. to Push for More Trade Liberalization at APEC" Reuters (11 July 1996).

"Some Asian Nations Opposed to U.S. Corruption Proposal" Japan Economic Newswire (27 May 1996).

B. Tarrant, "APEC Fudge Gives Good Nudge to WTO" Reuters (26 November 1996).

"A Backlash to Asian Values" Worldsource Online Inc. (4 December 1997).

"The APEC Photo-Op" The Providence Journal (3 December 1997).

Y. Shimbun, "Trade Ministers Agree to Fight Corruption" The Daily Yomiur (22 April 1996).

P. Parameswarun \& R. Coloma, "ASEAN Slams US Call to Include Corruption on WTO Agenda" Agence France Presse (25 April 1996). 
countries, put forth new public procurement rules that would criminalize bribes and require more transparency in the awarding of government contracts.

As expected, there was resistance to these proposals from a variety of developing countries. A group led by Malaysia and including Indonesia, Thailand, Brunei, the Philippines, Bahrain, Zimbabwe, Cuba, Egypt and Uganda argued that due regard be given to the national policies of each country. ${ }^{47}$

At the end of the conference, the WTO issued a declaration that a group was to be created to study and develop a multilateral agreement related to government procurement and, in particular, to promote its transparency.

The ministerial conference specifically agreed to:

(1) establish a working group to conduct a study on transparency in government procurement practices, taking into account national policies, and, based on this study, to develop elements for inclusion in an appropriate agreement; and

(2) direct the Council for Trade in Goods to undertake exploratory and analytical work, drawing on the work of other relevant international organizations, on the simplification of trade procedures in order to assess the scope for WTO rules in this area. ${ }^{48}$

The United States and the European Union have taken the view that an interim agreement on transparency emerging from this working group will eventually be upgraded into a full-blown agreement on government procurement practices to allow foreign companies access to government contracts equal to that of domestic companies. U.S. Trade Representative Charlene Barshefsky has said, "The study on procurement is intended to be the first step toward an agreement on transparency practice in government procurement which should serve to reduce the influence of corruption." As EU Commission Vice-President Leon Brittan has stated, "Europe is determined to see the proposed study forming the basis of a wider multilateral agreement providing for non-discrimination in government procurement." 49

\section{G. International Chamber OF COMMERCE}

In March 1996, the ICC approved and published its Rules of Conduct on extortion and bribery in international business transactions. ${ }^{\text {so }}$ December 1996).

4* WTO, Singapore Ministerial Organization, Art. 21 (13 December 1996).

49 "Government Must Retain Procurement Rights" Worldsource Online Inc. (18 February 1997).

so ICC, Extortion and Bribery in International Business Transactions, adopted by the Executive Board, 83rd sess., 26 March 1996. 
The new rules prohibit extortion and bribery for any purpose, not just to obtain or retain business, making them more stringent than the previous ICC Code published in 1977. The rules now cover extortion and bribery in judicial proceedings, tax matters, and environmental and other regulatory cases, as well as in legislative proceedings.

The ICC document includes recommendations for government action. It states that all governments, and particularly those of developing countries, should implement the recommendations issued in 1994 by the OECD. Action relating to the tax deductibility of bribes is of particular urgency. The ICC supports the growing practice of making government contracts dependent on undertakings to refrain from bribery. ${ }^{51}$

The ICC Rules of Conduct contain these main provisions:

(1) No enterprise may directly or indirectly offer or give a bribe and any demands for such a bribe must be rejected.

(2) Enterprises should not kick back any portion of a contract payment to employees of another contracting party.

(3) Enterprises should do everything in their power to ensure that payments to an agent represent no more than an appropriate remuneration for legitimate services.

(4) All financial transactions must be properly recorded and there must be no "offbook" or secret accounts.

(5) Enterprises should draw up their own codes consistent with the ICC rules to meet the particular circumstances of their business.

(6) Corporate governing bodies should establish control systems aimed at preventing payments that infringe ICC rules. They should take appropriate action against directors or employees who contravene the rules.

To promote the new rules, the ICC has set up a standing committee of business executives, lawyers and academics. National committees in sixty-two nations mobilize support for them in companies and business associations in their own countries. The committee will report every two years on progress in securing recognition of the rules.

\section{H. WORLD BANK}

In 1996, the World Bank put policies into place that required it to investigate complaints of corruption and if it found sufficient grounds, allowed it to blacklist companies and governments that participated in bribery. Under this policy, evidence of corruption could result in the cancellation of World Bank financing in a country and 
in the prevention of a bribing company from participating in contracts financed by the World Bank. ${ }^{52}$

The World Bank has made a clear public statement of its position in a report published in September 1997 entitled Helping Countries Combat Corruption: The Role of the World Bank. The report states that bribes are one of the primary elements of corruption which are used to obtain government contracts and services and that poorly regulated financial systems permeated with fraud "can undermine savings and deter foreign investment. They also make a country vulnerable to financial crises and macroeconomic instability." 53

The World Bank has begun to act against countries where corruption has been found in bank-financed projects. Masood Ahmed, head of the World Bank's poverty reduction and economic management network, stated that the bank had stopped funding development projects in Nigeria and Zaire and that it had launched strict reforms to improve the monitoring of its money. ${ }^{54}$ The World Bank also suspended a (U.S.) $\$ 76$ million loan to Kenya for energy development because it could not ensure that contracts would be awarded fairly and openly..$^{55}$ Developing countries have to take these actions seriously since the World Bank finances about 40,000 contracts worth (U.S.) $\$ 25$ billion each year.

\section{INTERNATIONAL MONETARY FUND}

On a similar basis, the IMF has denounced corruption in developing countries. ${ }^{56}$ As part of its monetary policy, it has urged countries wanting to borrow from the IMF to institute anti-corruption reforms.

The IMF has also acted closely with the World Bank against corrupt regimes. In August 1997, the IMF suspended a (U.S.) $\$ 220$ million loan to Kenya because of a scandal in the gold and diamond export trade. ${ }^{57}$ The next month, the IMF put a (U.S.) $\$ 120$ million loan to Cambodia on hold "because of problems in governance which concern corruption and logging."

One of the consequences of the IMF taking a leading role in resolving the financial crises of several Southeast Asian countries, is that it is imposing conditions on its loans that directly address corruption and bribery. South Korea has been forced to open its

$32 \quad$ P. Lewis, "A World Fed Up With Bribes" The New York Times (28 November 1996) DI.

53 "IMF, World Bank Deserve Praise for Broaching Graft" (Bangkok) Business Day (25 September 1997). See: Helping Countries Combat Corruption: The Role of the World Bank, Poverty Reduction \& Economic Management, The World Bank (September 1997). "World Bank Promotes New Anti-Graft Initiative" Associated Press (24 September 1997).

ss S. Meisler, "World Bank, IMF Taking Steps Against Corruption" Los Angeles Times (5 October 1997) A8.

s6 G.R. Chaddock, "Ethics in Business Dealings Urged by World Leaders" Christian Science Monitor (20 November 1996).

57 "World Bank, IMF Taking Steps Against Corruption," supra note 55.

5s "IMF, World Bank Deserve Praise for Broaching Graft," supra note 53. 
markets, curtail state-owned firms and crony capitalism, and make its financial systems more transparent. Thailand and Malaysia have been forced to accept the same recipe, despite the loud protests of Malaysian Prime Minister Dr. Mohamad Mahathir. Indonesia has been forced to order the closure of sixteen loss-making banks, including one owned by President Suharto's son. ${ }^{59}$

\section{J. Transparency InTERNATIONAL}

Transparency International (TI) was founded in May 1993 with headquarters in Germany. It is a not-for-profit, non-governmental organization that attempts to counter corruption in international business transactions. ${ }^{60}$ It does this through international and national coalitions which encourage governments to establish and implement effective law, policies and anti-corruption programs. A Canadian chapter of TI was established in November 1996. ${ }^{61}$

Each year, TI publishes a corruption index which lists the most and least corrupt countries in the world. Through this and other public means, it encourages corporations to operate at the highest level of integrity.

\section{K. SUMmaRY}

There clearly is growing support in international forums for the prevention of bribery and corrupt practices. It is occurring for a variety of reasons:

(1) U.S. Initiative: The United States has mounted a substantial global campaign to enshrine the concepts of criminalizing bribery and eliminating the tax deductibility of bribes in multilateral treaties and agreements. The U.S. wants a level playing field. It wants other countries' multinationals to play by the rules applicable to U.S. companies (i.e., the $F C P A$ ). This is clearly stated in the 1996 Annual Report to Congress of the Trade Promotion Coordinating Committee (TPCC). ${ }^{62}$

59 “Asian's Woes Political rather than Economic" The Canberra Times (2 December 1997) A10.

6) Transparency Intemational, Introducing TI (Brochure) (January 1996).

(1) Transparency International Canada, Introducing TI Canada (Brochure) (October 1996).

(12 The Executive Summary of the 1996 TPCC Annual Report states:

We have made tremendous progress on this issue in just the last year. In May, the OECD adopted a Recommendation which calls on members to deny the tax deductibility of bribes. Ministers made a political commitment to criminalize bribery and to consider specific proposals in 1997 to accomplish this goal. The Organization of American States (OAS) completed the world's first anti-corruption treaty which requires signatories to criminalize bribery of foreign officials. In the NAFTA-created NADBank, the U.S. won agreement from Mexico that its guidelines require companies to certify that they have not engaged in bribery in bank projects. We will seek consensus at the Singapore Trade Ministerial on a WTO interim procurement accord including disciplines on transparency, openness and due process. And the World Bank explicitly stated that it is the Bank's policy not to tolerate fraud or corruption on Bank-financed contracts by bidders or borrowers. Anti-bribery amendments to the World Bank's loan conditions, procurement rules, and standard bidding documents were approved in July 1996 . In the coming year, we will maintain this momentum through 
(2) Trade: With the recent success of the Uruguay Round and the continuing increase in world trade, there is growing support in international trade organizations for greater transparency in business transactions. ${ }^{63}$ Bribes eliminate competition, create inefficiencies and ultimately cost countries and consumers more money. ${ }^{64}$

(3) Media: The increasing spread and availability of global communication, e.g. CNN, has resulted in growing dissatisfaction in many countries' populations with the fact that politicians and public officials get rich through corrupt practices. Governments have fallen (Italy and Japan), ex-presidents have been sentenced to prison (South Korea) and large numbers of politicians and senior

the following steps:

- Accord top priority to achieve agreement to criminalize commercial bribery through the OECD in 1997;

- Monitor closely OECD countries' implementation of their commitments to eliminate the tax deductibility of bribes;

- Seek agreement at the Singapore WTO Ministerial on a firm schedule for negotiating and concluding the Interim Agreement on Government Procurement;

- Work in APEC and the Free Trade Area of the Americas (FTAA) to promote transparency and accountability in member countries' procurement practices and seek active support for Singapore Ministerial WTO negotiations;

- Create a process to urge the prompt implementation of the OAS Convention and signature and ratification by all OAS members;

- Continue work with international financial institutions to ensure they implement the G-7 mandate on increased transparency and standardization in procurement;

- Seek to strengthen Multilateral Development Bank (MDB) procurement oversight at MDB headquarters and oppose delegation of procurement oversight to field offices in project countries;

- Seek commitment of the World Bank and other regional MDBs to require companies to commit that they have not engaged in bribery in bank-financed projects and that they have corporate policies that prohibit bribery;

- Encourage the World Bank and other MDBs to take steps to ensure no bribery takes place in connection with any project for which they are providing financial assistance;

- Amend Ex-Im Bank's Supplier Certificate to minimize any possibility of bribery occurring in transactions in which Ex-Im Bank may support, and amend OPIC's Insurance application to strengthen anti-bribery provisions;

- Amend the U.S. government's Advocacy Guidelines to condition advocacy assistance on the firm and its foreign parent or affiliates: (1) not paying a bribe in connection with the transaction for which advocacy is sought, and (2) maintaining and enforcing a policy prohibiting the bribery of foreign officials;

- Establish at the Commerce Department a hotline for reporting possible instances of bribery of foreign officials by non-U.S. companies;

- Continue USAID efforts to ensure that bilateral donor groups counteract transnational bribery through controls on bilaterally funded procurement and through efforts to support good governance reforms;

- Support the activities of nongovernmental organizations like Transparency International in their efforts to combat international business corruption;

- Consult regularly with the business community for input on implementation of the commitments we have already obtained and new ideas on ways to curtail transnational bribery. 
public officials have been prosecuted and imprisoned (e.g. Italy, France, Japan, Mexico, Venezuela).

The following are likely outcomes of these trends on Canadian companies doing business in the international arena:

(1) The Canadian government will reinforce the non-tax deductibility of bribes and similar payments. It will also likely amend the Criminal Code to criminalize the payment of bribes to foreign officials. It will do this to fulfil its undertakings under the international agreements referred to above.

(2) The OAS Inter-American Convention Against Corruption and the OECD Convention on Combatting Bribery of Foreign Public Officials in International Business Transactions will likely set the trend on the issues of extradition and bank secrecy. If these become more common within and between regional trading areas, then overseas offenders will be aggressively pursued using these tools.

\section{Host Countries}

The following is a review of the laws relating to improper payments in several host countries. It provides a sampling of the kind of laws on corruption that one can expect to encounter.

\section{A. YEMEN}

Improper payments are governed in Yemen by the Criminal Law No. 12 of $1994 .^{65}$ They are considered bribes under this law. A person is considered to have committed the crime of bribery if he uses his influence to assist in carrying out a task in return for a payment or a promise to be paid.

The Criminal Law states that a bribe is anything (of any kind) offered to a public official, or anything (of any kind) promised to be given to a public official, to cause him to carry out a task, or to refrain from carrying out a specific task, which goes against the regulations of his job.

The Criminal Law also clearly describes a person offering to bribe another as "a person who asks a public official to carry out a specific task which goes against the employee's work regulations." The Criminal Law also states that an intermediary is "one who introduces the two parties together or assists in the crime of bribery or had knowledge of it." Such an intermediary will be considered to have committed the crime itself, and will be sentenced as such.

Article 158 of the Criminal Law states that an employee in the private sector who asks for a bribe for himself or others, or who was promised to be given a bribe (or a 
gift), without the knowledge of his employer, will be considered to have committed the crime of bribery and will be sentenced to a maximum of two years in prison or a maximum fine of 4,000 Yemeni Rials.

A person asking for a bribe for himself or any other person, who was an intermediary in the crime of bribery, or who was promised to receive moneys or other benefits from a foreign country, or from those working for the foreign country's interest, to carry out a task which will harm Yemen's interest, will be considered to have committed the crime of bribery, and will be sentenced to a maximum of ten years' imprisonment.

The sentencing for crimes of bribery is as follows:

(1) a maximum of ten years' imprisonment if a public official accepts a bribe, or asks for a bribe;

(2) a maximum of ten years' imprisonment if a public official accepts a bribe without knowing that he was carrying out a wrong or that he was carrying out an act which goes against the regulations of his job;

(3) a maximum of seven years' imprisonment if a public official accepts or asks for a bribe in the form of a gift to be given to him at the end of his task even if there was no previous arrangement for it; and

(4) a maximum of three years' imprisonment for anyone offering to bribe a public official even if the public official did not carry out the task.

B. LIBYA

Article 226 of the Criminal Code of Libya ${ }^{66}$ prohibits corrupt and improper payments and imposes a penalty of up to three years' imprisonment on individuals taking part in such acts.

\section{Nigeria}

Nigeria has the following anti-corruption laws:

(1) Criminal Code (1990); ${ }^{67}$ and

(2) Code of Conduct Bureau and Tribunal Act (1989). ${ }^{68}$

Section 98 of the Nigerian Criminal Code states that any person who gives or promises to give any property or benefit of any kind to a public official or any other 
person in order to obtain a contract, licence or permit from the government or other organization in which a public official is serving, is liable to imprisonment for seven years. The giving of the benefit must have been done corruptly, i.e., it must have been meant to sway or deflect a public official from the honest and impartial discharge of his duties.

Nigerian courts have held that it was not corrupt to induce a public official to merely do his duties. Also, the public official himself must have done or promised to do the corrupt act or the corrupt omission. Gifts, payments and benefits conferred on Nigerian public officials for merely doing their duty, if such payments or benefits are not excessive, are unlikely to be found to be corrupt under the Criminal Code.

The Code of Conduct Bureau and Tribunal Act has a more stringent standard which makes illegal the giving of an inducement to a public official merely to do his duty. However, there are other sections of this code which state that a public official may accept gifts or benefits from relatives or personal friends to such an extent and on such occasions as are recognized by custom.

The combined reading of the two statutes results in the conclusion that bribes that are corruptly given to obtain government contracts or business are illegal and offenders are subject to imprisonment. Facilitating payments for routine governmental action are acceptable under Nigerian law, as long as they satisfy the above-mentioned requirements.

\section{KaZAKSTAN}

The following statutes govern improper payments in Kazakstan:

(1) The Criminal Code of the Kazak Soviet Socialist Republic of 1959 (Amended $1986) ;{ }^{69}$ and

(2) Decree No. 9 of the Plenum of the Supreme Court of the Republic of Kazakstan (1995). ${ }^{70}$

Article 147 of the Criminal Code provides that the giving of a bribe is punishable by three to eight years' imprisonment. In the case of repeated acts of bribery or for persons previously convicted of corruption, the punishment is seven to fifteen years' imprisonment. Article 146(1) provides that a person acting as an intermediary of bribery is punishable by two to eight years' imprisonment, and for repeated acts the punishment is imprisonment from seven to fifteen years. 
Not every gift is considered a bribe. Government officials are subject to an internal regulation requiring that they turn over valuable gifts to the state, and relatively minor gifts are fairly common. Such matters as the value of the object given, social custom, and the importance and relevance of the official position may be taken into consideration by the prosecutor in deciding whether to lay charges. Enforcement of these provisions is often arbitrary and inconsistent. In some cases, seemingly minor acts have been severely punished, while other questionable practices of a substantive nature have been tolerated.

Plenum Decree No. 9 provides that the receipt of bribes applies not only to government officials but also to persons temporarily exercising official functions in state, social or private enterprises, as well as to institutions or organizations and persons who have the ability to influence the matter under consideration by other officials. It also provides that the bribe may consist of money, securities, valuables or other benefits.

At the present time the liability for corruption in Kazakstan is personal and individual, not corporate. However, under the Kazakstan Civil Code, "moral damages" has been interpreted to apply to juridical persons as well as to individuals, so the possibility cannot be excluded that corporate entities could face civil liability in certain circumstances related to improper payments.

\section{E. Colombia}

The law in Colombia concerning corrupt and improper payments is contained in the Anti-Corruption Statute (Law 190 of 1995). ${ }^{71}$

Under this statute, an individual who gives or offers money or other benefits to a public official to perform an act in the line of his duties, or to delay or omit such an act, is subject to a minimum of three years' and a maximum of six years' imprisonment and a fine of between fifty to 100 times the minimum monthly salary.

It is also a crime to obtain a benefit or favour from a public official in a matter that he handles or is about to handle. The minimum sentence for this crime is imprisonment for four to six years and a fine of fifty and 100 times the minimum monthly salary.

There is also a new crime on the improper use of privileged information. Any public official or private party that makes improper use of information in connection with his public functions in order to obtain a benefit for himself or a third party is subject to imprisonment for two to six years. 


\section{F. Venezuela}

In Venezuela, the Organic Law for the Protection of the Public Patrimony ${ }^{72}$ provides that corrupt payments are criminal and are punishable with fines and imprisonment (from six months to fifteen years) for the involved public officials and third parties. Employees of Petróleos de Venezuela S.A. and its affiliates are considered public officials.

\section{G. INDONESIA}

There are three pieces of legislation in Indonesia which govern bribery and corruption:

(1) Law No. 11 of 1980 Regarding Bribery; ${ }^{73}$

(2) The Penal Code; ${ }^{74}$ and

(3) Law No. 3 of 1971 Regarding Suppression of Criminal Corrupt Deeds. ${ }^{75}$

The first two statutes are fairly general in their coverage and are infrequently applied. Under the Bribery Law it is an offence for any person to give or promise something to a government official with the intention of persuading that official to do or not to do an act (in relation to his job) which is contrary to his authority or duty to the public interest. An offender may be imprisoned for up to five years or a fine may be imposed of up to fifteen million rupiah. The language of the Penal Code is basically the same as that of the Bribery Law; however, the penalties are somewhat less severe than those imposed under the Bribery Law.

The Anti-Corruption Law is the most comprehensive of the three statutes. It is applicable to both government officials and to anyone involved in acts of bribery or corruption. Corruption under the statute may consist of a gift or promise, as well as of an illegal payment and misuse of official position for personal benefit to the financial detriment of the Indonesian state. The penalties are severe and include imprisonment up to life and/or a fine of up to thirty million rupiah. The Indonesian state is also able to confiscate any property or business obtained by such deed and withdraw or revoke any rights so obtained.

(Republic of Venezuela).

(Republic of Indonesia) [hereinafter Bribery Law].

(Republic of Indonesia), 1915 [hereinafter Penal Code].

(Republic of Indonesia) [hereinafter Anti-Corruption Law]. 


\section{H. VIETNAM}

There are a multitude of laws in Vietnam which contain specific provisions related to bribery and corrupt practices, such as the investment, ${ }^{76}$ tax, ${ }^{77}$ banking ${ }^{78}$ and land laws. ${ }^{79}$ However, the primary law that governs this matter is the Criminal Code. ${ }^{80}$

Under the Vietnamese Criminal Code, any person who receives a bribe to do or not to do something for the benefit of the person offering the bribe is punishable by one to twelve years' imprisonment. Crimes of this nature with serious consequences may be punishable by life imprisonment or death. Any person who offers a bribe or acts as an intermediary is liable to imprisonment from six months to fifteen years, and in cases with serious consequences, may be subject to life imprisonment. As a further penalty for the above offences, part or the whole of the offender's assets may be confiscated.

\section{SUMMARY}

The laws concerning improper payments in host countries tend to have the following characteristics:

(1) they are often confusing and even contradictory;

(2) they tend not to reflect local customs and practice and are therefore often ignored;

(3) they are often applied arbitrarily and inconsistently;

(4) they cover public officials but usually not their relatives;

(5) the punishment is usually severe and consists of imprisonment or fines and occasionally death;

(6) the punishment tends to apply to individuals only (to both the briber and the bribee), but not to corporations; and

(7) the individuals most at risk are the company's employees and representatives who work or reside in the host country.

76 Law on the Promotion of Domestic Investments (Socialist Republic of Vietnam), 22 June 1994.

7 Law on Turnover Tax (Socialist Republic of Vietnam), 30 June 1990.

7* Ordinance on Banks, Credit Cooperatives and Financial Companies (Socialist Republic of Vietnam), 23 May 1990.

$79 \quad$ Land Law (Socialist Republic of Vietnam), 14 July 1993.

(So) (Socialist Republic of Vietnam). 


\section{Conclusion}

Legal counsel providing advice on improper payments to Canadian companies operating globally need to look to a variety of sources to give a proper opinion. The jurisdictions which are most relevant are Canada, the United States and the specific host countries in which the company's operations are located. New multilateral agreements will strengthen some of these laws and will make the bribery of foreign public officials by Canadian companies and their personnel a criminal offence.

Given the increased risks associated with these activities, Canadian companies need to implement policies on improper payments which should reflect appropriate compliance requirements and ensure that directors, officers, employees and agents fully meet these obligations. Appendix A provides a sample policy on improper payments that can act as a guideline for some of the issues that need to be addressed.

Ultimately, companies have to take a stand on the issue of improper payments. As very simply put at the beginning of this article, a company has to decide whether "honesty pays." It is very easy to turn a blind eye to bribery to meet short-term goals. However, if history is any guide, only companies with a reputation for integrity survive and prosper for the long term. 


\section{APPENDIX A}

\section{ABC Canadian Company}

Sample Policy on

Improper Payments ${ }^{81}$

The Company shall conduct its business in an honest and ethical manner reflecting the highest standards of integrity and in compliance with the relevant laws and regulations applicable to it.

\section{DEFINITIONS}

"agent"

"bribe"

"facilitating payment"

means a person or corporation who is retained by the Company to represent its business interests in a particular country.

means a giving or offering by one party to another party, either directly or through an intermediary, any reward, advantage or benefit of any kind, in order to influence the making or not making or implementation of a decision or act by the receiving party.

means $\mathrm{ABC}$ Canadian Company and its majority-owned subsidiaries.

means a person or corporation who supplies materials, labour or services to the Company.

means a permanent, temporary or contract employee of the Company.

means an act to obtain something of value by force, threats or persistent demands.

means a payment made solely to expedite or secure the performance of the following routine government actions only:

(i) obtaining licences, permits and other official documents to qualify to do business in a foreign country;

(ii) processing governmental papers, such as visas and work orders;

(iii) providing police protection, mail services and inspection of goods or contract performance;

(iv) providing telephone service, utilities, loading or unloading cargo and protecting perishable goods from deteriorating; and

\$1 This policy is drafted on the assumption that $\mathrm{ABC}$ Canadian Company qualifies as an issuer under SEC rules. Therefore, the standards set by the FCPA are incorporated into the policy, along with the 1996 ICC Rules of Conduct. 


\section{(v) actions of a similar nature.}

"improper

payment"

"kickback"

"public official" means either a bribe, kickback or an unreported facilitating payment.

means the payment or receipt of a portion of a contract payment. This includes a gift of significant value received from or given to a contractor.

means any officer or employee of a government or any of its agencies, or a government corporation, or any person acting in an official capacity for any such entity, and includes relatives of any such person.

\section{BRIBES}

The Company, its employees or its agents shall not:

(a) directly or indirectly offer or give a bribe, and any demands for such a bribe shall be rejected; or

(b) pay or offer anything of value to a public official, political party, party official or political candidate in order to corruptly influence any act within the recipient's official capacity, or to induce the recipient to violate his lawful duty, or to induce the recipient to use his influence with a government to affect or influence any act or decision of such government for the purpose of obtaining, retaining or directing business.

\section{KICKBACKS}

The Company, its employees or its agents shall not kick back any portion of a contract payment to employees of another contracting party, or utilize other techniques, such as subcontracts, purchase orders or consulting agreements, to channel payments to public officials, to employees of another contracting party, or to their relatives or business associates.

\section{EXTORTION}

The Company, its employees or its agents shall not, directly or indirectly, demand or accept a bribe.

\section{FACILITATING PAYMENTS}

(a) The Company discourages the use of facilitating payments. However, where deemed necessary, facilitating payments may be made in the following circumstances only: 
(i) the payment falls strictly within the definition of a facilitating payment;

(ii) due diligence has been conducted to ensure that both the payment and its amount are absolutely necessary to conduct the Company's business;

(iii) the payment has been properly recorded in reasonable detail which accurately and fairly reflects the transaction; and

(iv) any such payments have been reported on a quarterly basis to the internal auditor.

(b) Each country manager of the Company shall administer the policy on facilitating paynents within the boundaries of the country for which he is responsible. The country manager shall fully comply with the above requirements and shall act in the best interests of the Company at all times.

\section{AGENTS}

(a) Retaining Agents

Prior to retaining an agent, the following steps must be completed under the direction and approval of the

\section{(i) Due Diligence}

The of the Company shall properly research and document in writing the reputation, background and past performance of the prospective agent in the following areas:

- Management Information. Confirm the directors, officers and other members of management of the proposed agent, where applicable. Determine if any of them are government officials, political party officials or political candidates.

- Ownership Information. Confirm the stockholders, partners or other principals of the proposed agent, where applicable. Determine if any of them are government officials, political party officials or political candidates or related to any of the foregoing.

- Affiliations. Confirm the business and government affiliations of the proposed agent, his family and close associates.

- Qualifications. Confirm the relevant qualifications of the proposed agent or its management personnel to perform the services required in the contract.

- Financial Information. Examine the audited or unaudited financial statements of the proposed agent, where applicable, and confirm its ability to perform the services required in the contract.

- References. Obtain character and financial reference checks on the proposed agent. 
- Local Law. Confirm that the performance by the agent of the services required in the contract is consistent with local law. Obtain an opinion of local counsel if requested by the

- Compensation. Confirm that the level of compensation is reasonable, given the experience of the agent, the country where services are to be performed, the expected results, and the amount and difficulty of work to be performed.

- Employee Certification. The employee who is proposing retention of the agent shall certify that the agent has been personally interviewed and that there is no reason to believe that the agent has violated this Policy or will violate this policy regarding future activities on behalf of the Company.

\section{(ii) Contract}

The Company shall only retain an agent using a written agreement with the following provisions after having obtained approval from

- A precise definition of the scope of the agent's duties.

- The agent shall acknowledge that he understands the provisions of this Policy and agrees to comply with its terms as well as with any provisions of applicable law.

- The agent shall acknowledge that the contents of the agreement may be disclosed by the Company to third parties as appropriate.

- The agent shall provide representations and warranties that neither he nor any of his principals, staff, officers or key employees are public officials, candidates of political parties, or other persons who might assert illegal influence on the Company's behalf, and that he will promptly inform the Company of any changes.

- The Company expressly states that its choice of agent was made after considering factors that support a belief that the applicable law and this Policy would not be violated.

- Assignment of the agreement by the agent is prohibited without the Company's prior written consent.

- Payment shall be by cheque made out in the agent's name or by wire transferred to a bank account which is registered in the name of the agent.

- Travel, entertainment and other miscellaneous expenses shall not be paid without the Company's prior written approval, and detailed records of such expenses shall be kept. 
- The agreement shall provide for automatic termination without compensation in the event of an improper payment in violation of applicable law, or this Policy.

- The agent shall make annual certifications of its compliance with applicable law and this Policy and shall certify that none of the payments made to him by the Company have been directed towards a public official.

- The agent shall advise the Company of any accession to an official position.

- The Company has the right to audit the agent's agreement, including the expenses and invoices of the agent.

(b) Managing Agents

The Company shall take measures reasonably within its power to ensure that:

(i) any payment made to any agent represents no more than an appropriate remuneration for legitimate services rendered by such agent;

(ii) no part of any such payment is passed on by the agent as a bribe or otherwise in contravention of applicable law or this Policy;

(iii) it maintains a record of the names and terms of employment of all agents who are retained by it in connection with transactions with public bodies or state enterprises. This record shall be available for inspection by the Company's auditors and, upon specific request, by appropriate, dulyauthorized governmental authorities under conditions of confidentiality; and

(iv) the activities of the agent are appropriately monitored to ensure that there is no breach of applicable law or this Policy.

\section{FOREIGN JOINT VENTURE PARTNERS}

Prior to entering into any joint venture with a local partner or any entity associated with, or who deals with, local authorities, the Company shall conduct a due diligence search on the prospective partner similar to that required for retaining an agent. The Company shall obtain similar written representations and warranties from such local partner as is required of agents.

\section{CONTRACTORS}

All contractors of the Company shall be provided a copy of this Policy. Any agreement with a contractor shall include a provision that the Contractor must abide by this Policy at all times. 


\section{GIFTS AND ENTERTAINMENT}

The Company's executives are authorized to make gifts and to incur entertainment expenses for the purposes of expressing appreciation, generating goodwill or otherwise advancing the Company's business interests if they fall within the following guidelines:

- Reimbursed expenses connected with a public official's visit or with giving a public official samples or presents must be legal under the laws of the country of the recipient and considered customary in such country.

- There must be a business purpose behind the expenditure that justifies the expense.

- Expenses incurred under this Policy must be fully documented in writing.

\section{POLITICAL CONTRIBUTIONS}

Contributions to political parties or committees or to individual politicians may only be made in accordance with the applicable law, and all requirements for public disclosure of such contributions shall be fully complied with. All such contributions must be approved by the

\section{EMPLOYMENT}

No public official shall be employed, unless:

(a) the lawful in the country concerned; and has satisfied himself that such employment is

(b) the has determined that the services to be rendered the Company do not conflict in any manner with the governmental duties of such person.

\section{FINANCE}

(a) The Company shall make and keep books, records, and accounts which conform to high professional standards of accuracy and consistency and which, in reasonable detail, accurately and fairly reflect the Company's transactions and the disposition of its assets.

(b) All financial transactions must be properly and fairly recorded in such books of account and must be made available for inspection by the board of directors as well as by the Company's auditors.

(c) There must be no "off-book" or secret accounts, nor may any documents be issued which do not properly and fairly record the transactions to which they relate. 


\section{AUDIT}

(a) The internal auditor is responsible for auditing improper payments and accounting practices periodically at every significant business facility, and for informing the audit committee of every violation of this policy that comes to his attention. He shall also recommend procedures to prevent a recurrence of any such violation. He is also responsible for conducting special audits or investigations of suspected violations of this Policy.

(b) The internal auditor shall provide to the audit committee quarterly reports of any facilitating payments.

\section{COMPLIANCE}

(a) The

shall be responsible for the appropriate dissemination of this Policy and the procurement of a signed Statement of Compliance in the form of Exhibit A to this Policy on or before April 30 of each calendar year for each employee receiving an annual salary of $\$$ (or equivalent) or more. A copy of each such Statement of Compliance received in which question 2 is answered in the affirmative shall be sent to the chairman of the Audit Committee.

The shall have the responsibility of obtaining a signed Statement of Compliance in the form of Exhibit A from each newly hired employee receiving an annual salary of $\$$ whose salary increases to $\$$ (or equivalent) or more and from each employee (or equivalent) or more.

(b) Any employee who becomes aware of a prior or potential violation of this Policy is encouraged to contact the who shall report same immediately to the president and to the Audit Committee. A determination of whether a particular past or proposed payment or action is in violation of this Policy shall be made by the in consultation with the president and/or the chairman of the Audit Committee. Any employee making a bona fide report of an alleged violation shall be fully protected and indemnified.

(c) If an employee, agent or contractor is found to be in violation of this Policy, appropriate corrective action, including dismissal, shall be taken and immediately reported to the Audit Committee.

\section{RESPONSIBILITIES}

(a) The

is (are) responsible for establishing and maintaining the practices, procedures, and internal accounting controls necessary to implement this Policy and prevent any violation.

(b) The Audit Committee shall review compliance of this Policy on an annual basis and shall establish procedures for obtaining appropriate reports for the purpose of such review. 


\section{EXHIBIT A}

\section{STATEMENT OF COMPLianCE}

1. Have you read within the past twelve months, and do you understand, the Company's Improper Payments Policy?

Yes No

2. To the best of your knowledge have you at any time within the past twelve months been in violation of such Improper Payments Policy?

$$
\text { Yes __ No }
$$

3. Have you participated in the Company's training program on the Improper Payments Policy?

$$
\text { Yes _ No }
$$

4. If your answer to question 2 above is "yes," please give full details. 